\author{
Oksana Zakharova ${ }^{1}$
}

\title{
“THE STRUGGLE OF PAMPHLETS”(1791). UKRAINIAN DIPLOMATS IN LONDON AT THE END OF THE XVIIIth CENTURY
}

Keywords: international relations, public diplomacy, parliament, embassy, state image.

\begin{abstract}
Throughout the XVIIIth century, Anglo-Russian relations were very contentious. The Ochakov crisis of 1791 risked escalating into direct military action between Russia and England. Ambassador Count S.R. Vorontsov managed to garner the support of members of the House of Lords and the House of Commons of the English Parliament, come in contact with the Prime Minister, members of his cabinet and opposition leaders. The above mentioned allowed him to handle the possibilities of the press, publishing houses and the opposition during the Ochakov crisis of 1791 as well as influenced a public opinion in Britain. In large part, because of the active actions of S.R. Vorontsov and his office staff, it was possible to avoid an armed conflict between Russia and England.

One of the closest employees of Semyon Romanovich was the son of a Ukrainian priest Yakov Ivanovich Smirnov, who was considered by many contemporaries as one of the outstanding employees of the office of the Russian Embassy. Ya. I. Smirnov was knighted of the Order of St. John under Paul I, and then the Emperor's stunning decision took place - the priest was appointed charge d'affaires of Russia in London.

V.F. Malinovskiy, the future first director of the Tsarskoye Selo Lyceum, served in Vorontsov's office. After leaving London, he worked as a secretary at the negotiations in Iași in 1792.

As well as V.F. Malinovskiy, V.P. Kochubey hailed from Ukraine. The nephew of Count A.A. Bezborodko was in London from the early spring of 1789 until January of 1791. In 1793, Vorontsov gave V.P. Kochubey, who was diligently engaged in his education, a brilliant character reference. Over the course of his service, Count S.R. Vorontsov regularly defended the interests
\end{abstract}

1 Doctor of Historical Sciences, Professor, National Academy of Management of Culture and Arts, semendajtataana@jmail.com. ORCID: 0000-0002-2143-7020. 
of the employees of his office; he knew how to gather individuals for his inner circle and work. In the XIXth century, there was a concept of "official of the Vorontsov school".

S.R. Vorontsov and members of his office used the methods of modern public diplomacy, which implies means used by governments, private groups and particular persons to change the views of other people and governments in order to influence their external political decisions. Public diplomacy is a tool for creating the image of the state.

Appealing to public opinion, publication of government documents, use of the mass media and issuance of brochure for manifesting one's position are methods which play a crucial role in modern public diplomacy, which originated due to Ukrainian diplomats as well.

\section{INTRODUCTION}

The relevance of the research involves studying the methods through which S.R. Vorontsov and office staff of the Russian Embassy in London influenced the public opinion, which turned out to be decisive in preventing a military conflict between Russian and England.

The purpose of the article is to prove that to prevent military showdown of the Russian Empire and the British Empire in 1791 in London, there were used methods of modern public diplomacy, which also included publications in the printed press and mass media.

The author referred to the sources published in the Archive of Prince Vorontsov as well as unpublished works of the Archive of the Foreign Policy of the Russian Empire of the Ministry of Foreign Affairs of Russia.

The issue of origin and resolution of the Ochakov crisis of 1791 was considered by O.Yu. Zakharova in the monograph devoted to the life and activities of Count S.R. Vorontsov (Zakharova, 2013, p. 255).

The novelty of the research is the study of activities of Ukrainian diplomats in London at the end of the XVIIIth century.

\section{THE OCHAKOV CRISIS OF 1791}

All actions of the British Empire in 1790-1791 came down to the central aim - to establish hegemony in Europe. The Russian Empire hindered the accomplishment of the goal, and thus, it must be prevailed, 
weakened, forced to give up conducting active foreign policy. England and Prussia had tied a war with Sweden to it, which was dragged down until 1790 and undermined Russian impact both in Poland and in Europe. And by 1791 there was an immediate threat of war between Russia and England.

In a letter dated January 4, 1791, vice-chancellor I.A. Osterman informed the Russian ambassador S.R. Vorontsov that the British Ambassador Extraordinary to Russia Charles Whitworth received an instruction from London to repeat the proposal for reconciliation between Russia and Turkey (Osterman, 1791, p. 4). However, the conditions put forward were completely unacceptable for Russia. Although, without wishing to intensify the political stand-off, in early February Petersburg asked its envoy in Britain to speak wherever possible promoting explanations and statements that Russia was not going to send out a fleet to the Mediterranean Sea and that such information was spread by those who wanted to embroil Russia with England.

In correspondence with the royal court, S.R. Vorontsov proposed publishing documents rendering the positions of St. Petersburg and London towards the issue of peace with the Porte to bring their content to the notice of members of the Parliament and the English public. The Empress approved the proposal of the Russian ambassador by agreeing that it was necessary to open the English people's eyes to the truth. In June 1791, I.A. Osterman assisted S.R. Vorontsov in publishing copies of diplomatic documents on Anglo-Russian relations since 1788.

Actions of W. Pitt the Younger in that time showed the British ruling government was not going to stop pressure on Petersburg under any circumstances requiring an immediate (but on the terms set by Britain and its allies) end of the war with Turkey. The draft of the British summons on the end of the war with Turkey, sent to Berlin in March 1791, envisaged, for instance, Russia's giving up on Ochakov and the region between the Bug and the Dniester. To make Catherine more compliant, the Prime Minister even decided to send British combat ships to the Black and Baltic Seas and asked the House of Commons to provide military loans for reinforcing the fleet. 
The British government believed that the war with Russia was inevitable, and thus, gathered enormous naval forces: 36 battleships, 12 frigates and the same number of brigs and cutters (Vorontsov, 1876, p. 47).

In that situation, S.R. Vorontsov committed a very bold action as for a diplomat. He made a flush statement to the British Secretary of State for Foreign Affairs Godolphin Osborne, $5^{\text {th }}$ Duke of Leeds, that he would do everything in power to prevent "an unjust and adverse war for both countries". Addressing him, the Russian ambassador said that he had a high opinion of English common sense and, therefore, could not but "hope that the strong voice of public opinion will make you cancel this unjust campaign" (Vorontsov, 1876, p. 47).

S.V. Vorontsov energetically visited opposition leaders, some members of the lower house and influential representatives of the trade circles. In their conversations, he explained that England, its trade, banks would incur steep losses both from the war and the termination of trade relations with Russia.

The public sentiment of a wide variety of the British society was reflected in activities of the Whigs arguing against wars of conquest of the United Kingdom. Being represented by its brilliant speakers and publicists Ch. J. Fox, R.B. Sheridan, F. Francis, the party permanently exposed the militant policy of Pitt the Younger and his office in the parliament. The ruling party was particularly criticized for the conduct of territorial seizures in India and putting the Anglo-Prussian alliance against Russia.

One of the prominent representatives of the opposition, Gray, who submitted a request about preparations for a war with Russia to the House of Commons, said: "Out trade relations with Russia always were the most beneficial. It supplied our manufactories with materials and was a perfect harbor for our sailors. Our exports to Russia reached 2 million pounds annually, and our imports - 1 million. Export duties were 300,000 pounds annually. More than 350 ships, almost entirely, were involved in that trade, with the exception of four or five British. The question is: is it wise, is it prudent to interrupt that sort of trade?" (Steinberg, 1943, p. 37).

S.R. Vorontsov addressed to Ch. J. Fox, one of the most influential representatives of the Whigs and a man of great rhetorical power, with 
a request to affect the representatives of the British Cabinet Ministers and put into perspective negatively unfolding situation.

At the same time, the number of Pitt's opponents as well as their pressure on the public opinion was growing up every day in England. The prime minister was forced to urgently send a special envoy on the heels of a harbinger forwarded to St. Petersburg with a note in which Russia would be declared war, if it did not conclude peace with Porte immediately and didn't return everything conquered within the Turkish borders to it. However, even after recalling the harbinger, he continued to arm the fleet at Portsmouth.

Realizing that it was too early for a victory celebration, S.R. Vorontsov sent notes and brochures to the manufacturing centers of England, in which he explained to citizens that the cessation of trade with Russia would lead the nation to ruin (Vorontsov, 1876, p. 49). According to A.M. Stanislavskaya's research, "using the rich statistical material collected by S.R. Vorontsov and his staff, the authors of the brochures "People's Capital" and "Appeal to the British People" proved the exceptional profitability of trade with Russia for England ... Particular difficulties of the war with Russia, invulnerable due to its geographical position, were highlighted; it was pointed out that the British fleet would be powerless against the fortified defense of Revel and Kronstadt, and the Russian soldiers were incomparably far better than the Prussian ones" (Stanislavskaya, 1957, p. 117).

Monsieur Joly, Vorontsov's private secretary, and John Paradise, Fellow of the Royal Society, D.C.L of Oxford University, linguist and literary figure, were directly involved in collecting factual and numeric data for the Russian diplomat and in a war of pamphlets. Thus, at S.R. Vorontsov's request, Joly composed the essay in French and translated it into English entitled "Serious Enquiries into the Motives and Consequences of our Present Armament against Russia", which would be widely disseminated. Paradise, who was well-connected in literary and academic circles of London, assisted Russian diplomatic officials to get in touch with all important people in the British capital.

In that anxious moment, a merit of Count S.R. Vorontsov was that the brochures, which he had prepared in vast numbers, were published earlier 
than publications popularizing the government's anti-Russian policy. In April, the diplomat was glad to inform his brother Count S.R. Vorontsov that in London there was not a single brochure defending the policy of V. Pitt.

The Russian envoy could quite successfully influence the public opinion of England (Stanislavskaya, 1957, p. 116). On April 10, 1792, a meeting convened "upon demand of many big traders, owners of a textile mill et al." took place in Manchester. The main points of his resolution came to the statement that the United Kingdom, being a country with heavy taxes and debt, should not take part (unless necessary) in armed hostilities. The meeting's participants concluded that there were not reasonable causes for the involvement of the state in a war with Russia and thus, knights of the shire had to argue against imposing a new military burden on the people. On April 19, participants of the next meeting adopted the resolution requiring Manchester's parliamentary representatives to vote against war credits.

On April 28, the Manchester resolution was supported by meeting participants in Wakefield. At the same time, it was marked that the export of wool to Russia from the county of York reached 200-300 thousand pounds sterling, and the loss of the Russian market would deal a serious blow to the interests of the county. In Norwich, Leeds, and Manchester, public meetings held and petitions to parliament, expressing an objection against activities of the ministry regarding Russia, were written up. Voters appealed to their representatives with the demand to remove Pitt from the post of prime minister. In London, words on the walls of houses appeared: "We do not want war against Russia". Every day, more than 20 newspapers printed anti-war articles the secret authors of which were Vorontsov's assistants, embassy workers, who elucidated the extreme inexpedience of the conflict with Russia to the British (Vorontsov, 1876, p. 49).

A few days earlier, on April 15 of the same year, Ch. J. Fox said in the Parliament that the growth of Russian influence posed no danger for England, since "the extensiveness of its territory, the insignificance of its income and the low population density make its power not dangerous for us in any way". Using documents gathered by Vorontsov for his speech, he argued that Ochakov was not a trigger for a war with Russia. And the 
future opposition leader Gray noted that the conquest of Ochakov by the Russians didn't provide Russia with dominance over the Dniester navigation.

The political crisis increasing apace brought Pitt to give up and come to terms with the opposition. At the cabinet meeting, it was decided not to send British ships to the Black Sea and the Baltic, as well as not to issue the summons to Russia. The Duke of Leeds, who signed it, resigned office on April 21.

The next day, the Russian ambassador wrote to St. Petersburg: "This entire situation, which seemed sticky at the start, has taken a very fortunate turn for our interests" (Stanislavskaya, 1957, p. 118). In 1791, the envoy worked so enthusiastically and so skillfully built relationships with British politicians and trading companies that he managed to have a major impact on the press, publishing houses and, most importantly, public opinion. All the above actions along with eloquent speeches of opposition members in the parliament triggered distrust of the policy of ruling cabinet even among Pitt's supporters.

After making peace with Turkey on December 29 (under the Julian calendar) 1791, the Russian envoy to the United Kingdom, approving tough, protecting the interests of Russia, actions of the Empress, wrote to Chancellor A.A. Bezborodko in Petersburg: "Stability is the foremost quality of a man: mind and knowledge without it mean nothing; on the contrary, they make despicable one who has a piece of childishness towards thoughtfulness and fundamentals" (Vorontsov, 1791, p. 486). Vorontsov liked to repeat that "there is nothing more glorious and more useful than peace concluded under the sword".

The events of spring and summer of 1791, named the Ochakov crisis, marked the beginning of the building of new relations between Russia and England. At the same time, revolutionary France, contrary to England's expectations, didn't drop the active foreign policy. Due to various political collisions, in February of 1793, the Anglo-French war started, and V. Pitt needed a powerful ally such as the Russian Empire. Then, S.R. Vorontsov bent every effort to mend fences between Russia and Britain. 


\section{EMBASSY OFFICE}

During the Ochakov crisis, the "Vorontsov's ministry" in London acted firmly and decisively. The diplomatic victory of 1791 would hardly have taken place without the team-up work of employees of the embassy's chancellery, each of whom was characterized by high professionalism. There was no a fixed staff of the Russian Embassy until 1779. In 1711, Kurakin only had had a secretary; Kantemir's staff had varied from five to seven employees. In 1779, the staff strength of the embassy consisted of six persons: one counselor of the embassy, two titular counselors, one translator and two probationary employees. Embassy officials were constantly in debt. An embassy secretary in London earned 300 rubles under Peter I, and 400-600 rubles under Elizabeth. Almost all embassy expenses, including the sending of diplomatic letters, were funded by S.R. Vorontsov. Only in 1795, S.R. Vorontsov dared to remind the authorities that his financial situation was very dire and, therefore, he asked the Empress to pay at least the postage costs $-200-300$ pounds sterling. Thanks to the efforts of S.R. Vorontsov, the allowance of embassy officials was increased by the end of the century. According to the staff, in 1800 it amounted to 2500 rubles for a secretary and 1000 rubles per person for two clerks.

One of right-hand men of Semyon Romanovich was Yakov Ivanovich Smyrnov, the son of a Ukrainian priest, who was considered by many contemporaries as one of the outstanding employees of the office of the Russian Embassy. In 1776, being in Kharkov, Archpriest Andrey Afanasyevich Samborskiy selected, according to the permit of Archpriest of Belgrade Haggai, several young people for conducting church service in the London Church and training of agriculture. Yakov Linitsky was among them. However, on the way from Kharkov to St. Petersburg, Samborskiy convinced the youth that some capital officials were not friendly towards Ukrainians, and the trip to England might not take place. As a result, the names of selected persons were changed in Moscow. Thus, Yakov Linitskiy became Yakov Smirnov (in Latin, "lenison" means quiet or meek) (Zakharova, 2013, p. 100).

In the opinion of Count E.F. Komarovskiy: "In the context of our mission in London, there was one good man among all officials - a priest of 
our church Ivan Yakovich Smirnov, who is also involved in the diplomatic affairs. Smirnov is "a very clever man, who is proficient in Latin, speaks French, German, English and (if I am not mistaken) Italian - he reads a lot, translates and writes. He adores the British; that's why the British love him. I don't think he would want to live anywhere other than London", - wrote journalist and writer P.I. Makarov, who visited the Russian priest in 1795. Describing the appearance of Yakov Ivanovich, he marked his stateliness, high stature, good shape, elegance of the suit; "[...] in brief, young, good-mannered lord [...]. Smirnov's appearance was in harmony with his moral virtues; P.I. Sumarokov, A.I. Turgenev, F.I. Jordan highlighted kindness and care of Yakov Ivanovich. Wanting to improve the financial situation of an employee of his office, Vorontsov, in one of his letters as of 1786 to Bezborodko, asked "to obtain by petition [...] reward and some annual financial aid from our dear and generous Empress. [...] $\mathrm{He}$ (Ya. I. Smirnov - author's note) is in the grip of poverty, having a wife and five children [...]" (Vorontsov, 1786, p. 465). Semyon Romanovich characterized his assistance as a man of action and ability, who was held in respect not only among fellow citizens but also representatives of the British society. His duties included the recruitment of teachers for Russians, sending of tools for educational institutions and, in particular cases, even correspondence encryption.

Ya. I. Smirnov was knighted of the Order of St. John under Paul I, and then the Emperor's stunning decision took place. After S.R. Vorontsov's abandonment of the post of ambassador in 1800, the priest was appointed charge d'affaires of Russia in London. Vorontsov believed that, despite Smirnov's multiplicity of duties, his main task was to preserve the Orthodox Church. In 1817, the Holy Synod elevated Ya. Smirnov to the rank of archpriest.

S.R. Vorontsov highly appreciated not only the professional but also the moral qualities of his subordinates. Regardless of "hard", in his phrase, labour of office employees in 1791, they didn't leave the embassy not getting a promotion, although the transfer of his subordinates to other missions guaranteed them career progress. S.R. Vorontsov considered that the authorities were the most unfair to one of the embassy employees - Vasiliy Grigorevich Lizakevich, who, having worked in London for thirty-three 
years, served as chargé d'affaires many times. Semyon Romanovich asked Petersburg, when he was discharged from service, to take into account special merits, age and allow him to stay in England saving his salary (Vorontsov, 1876, p. 54).

S.R. Vorontsov treated Vasiliy Grigorevich as an extremely capable employee, one of the best cipher officers, who "would rather put a bullet through his head than sell our crypts".

In 1800 V.G. Lizakevich headed the embassy for a while but was soon appointed envoy to Copenhagen. On October 10, 1800, he wrote to Vorontsov: "Now I realize and feel even better than ever that there will be no happiness for me anywhere as in England and under your auspice, my unparalleled benefactor" (Lizakevich, 1800, p. 58).

V.F. Malinovskiy, the future first director of the Tsarskoye Selo Lyceum, graduate of Moscow University, an officer of Collegium of Foreign Affairs, worked in Vorontsov's office.

In 1789 , according to his version, he "begged to cooperate with London ambassador, being keen to discover the state glorified by wisdom and happiness of its government and residents, not caring about the benefits of service" (Zakharova, 2013, p. 102). After serving for two years in London, V.F. Malinovskiy returned to Russia with an excellent recommendation and, referring to the ambassador's positive compliment, he asked the chancellor for the vacancy of a Russian-language freight forwarder. (His wife was the daughter of the priest A.A. Samborskoy, who served in the Russian Church in London for many years, and English wife).

In S.R. Vorontsov's country house in Richmond, V.F. Malinovskiy finished the first part of the book "Thoughts on War and Peace". In his opinion, a true hero is a wise legislator who brought peace and prosperity to the people. "The British - he wrote - get general respect in Europe due their great people with virtues, the improvement of their government and their personal properties" (Malinovskiy, 1958, p. 50). After leaving London, he worked as a secretary of the Russian delegation at the negotiations in Iași in 1792.

V.P. Kochubey translated the text of the Treaty of Jassy in French for Mr Fox. The nephew of the powerful Count Bezborodko hailed from Ukraine, as well as Malinovskiy. Kochubey stayed in London from the 
early spring of 1789 to the beginning of January of 1791. A year after studying and traveling in France and Switzerland, he returned to the British capital. If in 1789, S.R. Vorontsov wrote in one of his letters that Kochubey belonged to the number of promising young people, four years after, on July 6 (June 25), 1793, in a letter to P.A. Zubov, he gave a brilliant character reference of V.P. Kochubey, who, according to him, was diligently engaged in science and his education while residing in London. As a result, he not only mastered French, German and English but also knew the ropes of a political situation in Europe. "His modest conduct augments his merits and has attracted the personal respect of honored people for him. At the age of 25, he is characterized by the stability of a 40 -year-old man" (Vorontsov, 1793, p. 145, 420). Consequently, Kochubey was included in the Private Committee the members of which (A. Chartorizhskiy, P. Stroganov, N. Novosiltsev and V. Kochubey) shared, inter alia, love of England. Moreover, Kochubey "knew the composition of the parliament, the rights of its members better than anyone else, read all English publicists and, like a lion cub of the Krylov's Fable, was going to teach animals to build nests", - the memoirist F.F. Vigel wrote about him (Vigel, 2000, p. 100).

The ambassador didn't seek to expand the permanent staff of his office as its funding was very moderate. At the same time, a wide range of responsibilities did not allow him to reduce the staff strength of the embassy. According to Vorontsov, the number of employees in the embassy office should not be reduced under any circumstances, since all four of its employees "are continuously being involved in reading, translating and writing". Besides, they dealt with issues of a kind of "tutelage" of students sent to England by the Board of Admiralty for shipbuilding training and Russian officers serving in the British Navy. In 1797, S.R. Vorontsov asked Count A.A. Bezborodko not only to keep Lizakevich, Nazarevskiy, Smirnov and Sivers under his authority but also to solicit Emperor about their reward. He knew how to gather individuals for his inner circle and for work. He imparted that skill to his son. In the XIXth century there was a concept "official of the Vorontsov school" (Vorontsov, 1797, p. 247-248). 


\section{CONCLUSIONS}

S.R. Vorontsov and members of his office used the methods of modern public diplomacy, which implies means used by governments, private groups and particular persons to change the views of other people and governments in order to influence their external political decisions. Public diplomacy is a tool for creating the image of the state.

Appealing to public opinion, publication of government documents, use of the mass media and issuance of brochure for manifesting one's position are methods which play a crucial role in modern public diplomacy, which originated due to Ukrainian diplomats as well.

\section{BIBLIOGRAPHY:}

Vigel, F.F. (2000). Zapisi [Entries]. Moscow, p. 100.

Vorontsov, S.R. (1876). Avtobiografiya [Autobiography]. Russian archive. pp. 47, 49, 54.

Vorontsov, S.R. (1786). Pis'mo A.A. Bezborodko [Letter to A.A. Bezborodko]. London. Archive of Prince Vorontsov. Book. 9. pp. 465.

Vorontsov, S.R. (1791). Pis'mo A.A. Bezborodko [Letter to A.A. Bezborodko]. London. Archive of Prince Vorontsov. Book. 9, pp. 486.

Vorontsov, S.R. (1797) Pis'mo A.A. Bezborodko [Letter to A.A. Bezborodko]. London. Archive of Prince Vorontsov. Book 9. pp. 247-248.

Vorontsov, S.R. (1791). Pis'mo A.R. Vorontsovu [Letter to A.R. Vorontsov]. London. Archive of Prince Vorontsov. Book. 9. pp. 190.

Vorontsov, S.R. (1793 ). Pis'mo P.A. Zubovu [Letter from P.A.Zubov]. London. Archive of Prince Vorontsov. Book 9. p. 145, 420.

Zakharova, O.Yu. (2013). Zhizn' i diplomaticheskaya deyatel'nost' grafa S.R. Vorontsova [Life and diplomatic activities of Count S.R. Vorontsov]. Moscow, p. 100, 102.

Lizakevich, V.G. (1800). Pis'mo S.R. Vorontsovu [Letter to S.R. Vorontsov]. Copenhagen, Archive of Prince Vorontsov. Book. 9, pp. 58.

Malinovsky, V.F. (1958). Izbrannyye obshchestvenno-politicheskiye sochineniya [Selected socio-political works]. Moscow, pp. 50.

Osterman, I.A. (1791). Pis'mo S.R. Vorontsovu [Letter to S.R. Vorontsov]. S. Petersburg. Archive of the foreign policy of the Russian Empire of the Russian Foreign Ministry. F. 36. Op. 1.D. 453. L.4. 
Stanislavskaya, A.M. (1957). Anglo-russkiye otnosheniya v kontse XVIII v. [Anglo-Russian relations at the end of the $18^{\text {th }}$ century]. Reports and communications of the Institute of History. Release 12. Moscow, pp. 117, 116, 118.

Steinberg, E. (1943). S.R. Vorontsov i anglo- russkiye otnosheniya na rubezhe XVIII-XIX vekov [S.R. Vorontsov and Anglo-Russian relations at the turn of the XVIII-XIX centuries]. Historical journal. No. 11-12, pp. 37. 